Dostupné z: http://www.ped.muni.cz/capv2011/sbornikprispevku/pavelkovasaitlova.pdf

\title{
Instrumentalita učení z hlediska budoucích cílů
}

\section{Learning instrumentality from the point of view of future goals}

\author{
Isabella Pavelková, Barbora Saitlová
}

\begin{abstract}
Anotace: Ve stati tematizujeme problematiku subjektivního významu učení z hlediska životních cílů a atribučních tendencí žáků. Představujeme vybrané výsledky pilotní studie realizované v roce 2011. Cílem studie bylo zmapovat u studentů SOU ( $=126)$, jakou připisují jednotlivým životním cílům důležitost, jakou připisují instrumentalitu učení pro splnění těchto cílů a jaké mají atribuční tendence při jejich plnění. Studie potvrzuje oprávněnost odlišovat důležitost cílů od proměnné instrumentalita učení. Potvrzen byl i význam vnitřních atribučních tendencí u studentů.
\end{abstract}

Klíčová slova: důležitost cílů, instrumentalita učení, atribuce, motivace

\begin{abstract}
In our essay we thematize a problem of subjective learning importance from the point of view of pupils' life goals and attribution tendencies. We introduce selected results of study implemented in 2011. The goal of study was map, what importance secondary school students $(\mathrm{n}=126)$ ascribe to life goals, what learning instrumentality they ascribe to fulfilment these goals and whwhat attribution tendencies they have. The study confirms legitimacy of differentiate between goals importance and learning instrumentality. The importance of students' internal attribution was confirmed too.
\end{abstract}

Keywords: goals importance, learning instrumentality, attribution, motivation

\section{1 Úvodem}

Vedle nedostatečné motivace, což bývá nejčastějším důvodem selhání studentů ve škole, může být problémem i určitá bezradnost či neschopnost vědět si sám se sebou rady při ztvárňování vlastního života. Učitelé i rodiče upozorňují na určitou neochotu některých studentů přebírat zodpovědnost za své vzdělávání a za svoji životní cestu. Otázky reflexe životní cesty - projekt vlastní budoucnosti proto považujeme za zvláště významný motivačně kognitivní činitel, ovlivňující závažná rozhodnutí, interpretaci událostí a realizaci životních cílů. V tomto ohledu je důležité analyzovat, jak jedinec percipuje, interpretuje a hodnotí místo, váhu a funkci vzdělávání (učení se) při projektování (anticipaci) své životní cesty (Pavelková, Purková, Menšíková 2010). Žákovská motivace se tak dostává do časových souvislostí života individua a úzce souvisí s autoregulací (respektive vzdělávací autoregulací).

\section{Cíle pilotní studie}

Cílem pilotní studie bylo orientačně zmapovat u studentů SOU: 
- připisovanou důležitost vybraným cílům;

- instrumetalitu učení pro tyto cíle;

- atribuční tendence při plnění sledovaných cílů;

- vazby mezi sledovanými proměnnými a motivační propojení sledovaných proměnných $\mathrm{s}$ úspěšností ve škole a volními vlastnostmi studentů.

V př́spěvku se věnujeme jen prvním třem bodům.

\section{Výzkumné metody a výzkumný vzorek}

Základní metodou výzkumu byla upravená verze Dotazníku důležitosti motivačních cílů a instrumentality studia pro splnění těchto cílů De Voldera a Lense (1982). Za základ dotazníku autoři použili inventár 23 motivačních cílů, majících různou časovou a obsahovou charakteristiku. Inventár cílů byl získán faktorovou analýzou odpovědí v Nuttinově (1980) Metodě motivační indukce - MIM.

Důležitost každého motivačního cíle je měřena na čtyřbodové škále (nedůležitý, málo důležitý, více důležitý, velmi důležitý). Přehled vybraných cílů viz tabulka 1.

Instrumentalita učení byla zjišt'ována u identických motivačních cílů jako subjektivní důležitost. Pro každý cíl posuzovaly pokusné osoby na čtyřbodové škále (jistě dosáhnu, spíše dosáhnu, spíše nedosáhnu, nedosáhnu) subjektivní pravděpodobnost dosažení cíle, jestliže se budou intenzivně učit a jestliže se učit nebudou. Pro každý cíl definuje rozdíl mezi těmito subjektivními pravděpodobnostmi instrumentální hodnotu studia pro jeho dosažení.

Při konstrukci dotazníku měřícího instrumentalitu učení se autoři opírají o myšlenky Irwina (1971) a Heckhausena (1977): Čin je vnímán jako instrumentální, jestliže jeho provedení zvyšuje subjektivní pravděpodobnost dosažení cíle, a naopak, jestliže čin v ničem nemění subjektivní pravděpodobnost dosažení cíle, je jeho instrumentalita nulová. Stupeň instrumentality nějakého činu se tedy měří podle rozdílu, který vytváŕí v subjektivní pravděpodobnosti cíle, jehož se má dosáhnout.

Atribuční tendence - Dotazník důležitosti cílů jsme doplnili ještě o zjištění atribučních tendencí u jednotlivých cílů. Východiskem je atribučně - motivační teorie B. Weinera (1980; 2005). Pokusné osoby jsme vyzvali, aby určily př́íčinu, která by $\mathrm{v}$ jejich př́padě nejpravděpodobněji vedla $\mathrm{k}$ dosažení daného cíle. V souladu s Weinerem jsme schopnosti považovali za příčinu vnitřní, stabilní a nekontrolovatelnou, úsili (píli) za př́icinu vnitřní, nestabilní a kontrolovatelnou, obtižnost úkolu za příčinu vnější, stabilní a nekontrolovatelnou a náhodu (štěstí) za prríčinu vnější, nestabilní a nekontrolovatelnou.

Atribuční procesy probíhající ve školních situacích jsou důležité pro pochopení autoregulační zdatnosti žáka, zároveň nám jejich zkoumání pomáhá porozumět vnímané instrumentalitě a dalším sledovaným proměnným. Obecné zákonitosti a zvláštnosti atribučního procesu v motivační problematice z hlediska žáka, resp. učitele jsme již dř́ve popsali (Hrabal, Man, Pavelková, 1989; Pavelková, 2002). Další studie (Saitlová, 2009), zaměřená na atribuční tendence v rámci konkrétní školní situace a na srovnání atribučních tendencí směrem do minulosti a do budoucnosti, ukázala, že je-li realita neočekávaná a zároveň jasně čitelná, dochází k výrazným změnám atribučních tendencí, kdy do hry vstupují situační proměnné zde především vnímaná obtížnost situace (testu) a očekávání úspěchu/neúspěchu v testu. Pokud je ale realita očekávaná, není výjimečná, dostávají se do popředí spíše stálejší individuální atribuční tendence. 
Stejně jako se mohou měnit atribuční tendence v závislosti na konkrétní situaci, může se pravděpodobně měnit i námi sledovaná instrumentalita učení, jestliže žák začne určitý cíl realizovat. Významnou roli pak budou nejspíš sehrávat obecné volní charakteristiky jedince a konkrétní situace (náročnost cíle, pomoc druhých apod.). Volní vlastnosti jsme ve výzkumu sledovali pomocí upravené formy dotazníku VCI (Kuhl, Fuhrmann).

Výzkumný vzorek pilotní studie tvořilo 6 tříd SOU ( $\mathrm{n}=126$ studentů). V dalším kroku budeme výsledky srovnávat s výzkumem realizovaným v roce 2010 na 4 SŠ $(n=323)$.

\section{Výsledky pilotní studie}

\subsection{Důležitost cílů a instrumentalita učení pro splnění cílů}

Výsledky popisné statistiky - důležitost jednotlivých cílů přináší tabulka 1. Největší důležitost má pro respondenty cíl Vystudovat střední školu. Jak naznačuje směrodatná odchylka, je ve vnímání důležitosti tohoto cíle velká shoda. Velká důležitost se potvrdila i u bloku cílů ze sociální oblasti (partnerské a kamarádské vztahy, št’astný rodinný život...). Mezi velmi důležité cíle se zařadil i cíl Řídit si sám svůj život a cíl Úspěšná pracovní kariéra. Z nabízených cílů naopak za nejméně důležitý byl označen cíl Vystudovat vysokou školu a cíl Hodně cestovat.

Tabulka 1

Důležitost a instrumentalita cílů

\begin{tabular}{|l|c|c|c|c|c|c|}
\hline & \multicolumn{3}{|c|}{ Důležitost } & \multicolumn{3}{c|}{ Instrumentalita } \\
\hline Cíl & Průměr & SD & Pořadí & Prüměr & SD & Pořadí \\
\hline Vystudovat střední školu & 3,85 & 0,39 & 1 & 1,46 & 1,10 & 1 \\
\hline Dobře vychovávat děti & 3,73 & 0,57 & 2 & 0,59 & 1,35 & 15 \\
\hline Být s tím, koho mám rád & 3,70 & 0,53 & 3 & 0,29 & 1,29 & 20 \\
\hline Mít úspěšnou pracovní kariéru & 3,69 & 0,56 & 4 & 1,41 & 1,06 & 2 \\
\hline Rídit si sám svůj život & 3,63 & 0,62 & 5 & 0,56 & 1,17 & 16 \\
\hline Žít št'astný rodinný život & 3,62 & 0,68 & 6 & 0,61 & 1,22 & 14 \\
\hline Mít milujícího partnera & 3,61 & 0,66 & 7 & 0,36 & 1,30 & 19 \\
\hline Stále se v něčem zlepšovat & 3,56 & 0,53 & 8 & 0,99 & 1,24 & 9 \\
\hline Vydělávat hodně peněz & 3,52 & 0,65 & 9 & 1,33 & 1,16 & 5 \\
\hline Být dobrým kamarádem & 3,51 & 0,67 & 10 & 0,28 & 1,17 & 21 \\
\hline Udržovat se ve zdravé kondici & 3,48 & 0,73 & 11 & 0,46 & 1,28 & 17 \\
\hline Mít zajímavé povolání & 3,36 & 0,76 & 12 & 1,17 & 1,11 & 6 \\
\hline Mít hodně kamarádů & 3,35 & 0,80 & 13 & 0,09 & 1,26 & 22 \\
\hline Osamostatnit se od rodičů & 3,29 & 0,82 & 14 & 0,64 & 1,37 & 13 \\
\hline Mít dobré známky & 3,28 & 0,68 & 15 & 1,39 & 1,19 & 3 \\
\hline Mít dostatek volného času & 3,24 & 0,74 & 16 & $-0,20$ & 1,46 & 23 \\
\hline Stále poznávat něco nového & 3,21 & 0,70 & 17 & 0,80 & 1,22 & 11 \\
\hline V životě dosáhnout něčeho významného & 3,17 & 0,80 & 18 & 1,00 & 1,10 & 8 \\
\hline Mít vysoký sociální status & 3,03 & 0,85 & 19 & 1,13 & 1,24 & 7 \\
\hline Pomáhat druhým & 2,98 & 0,75 & 20 & 0,39 & 1,15 & 18 \\
\hline Mít velký majetek & 2,66 & 0,83 & 21 & 0,86 & 1,23 & 10 \\
\hline Hodně cestovat & 2,16 & 0,77 & 22 & 0,68 & 1,21 & 12 \\
\hline Vystudovat vysokou školu & 2,00 & 0,91 & 23 & 1,35 & 1,44 & 4 \\
\hline Pozn: SD = š́n
\end{tabular}

Pozn.: SD = směrodatná odchylka 
V druhém kroku jsme zjišt’ovali instrumentalitu učení pro dosažení jednotlivých cílů (tabulka 1). Celková (obecná) instrumentalita učení není prŕiliš velká. Nejvyšší je u cíle Vystudovat střední školu (průměr 1,46), což představuje posun přibližně o 1,5 stupně v pravděpodobnosti, že studenti cíle dosáhnou, když se budou učit, ve srovnání s tím, když se učit nebudou. Podobně vysoká je instrumentalita také u cílů Mít úspěšnou pracovní kariéru a Mít dobré známky. U jednoho cíle (Mít dostatek volného času) je instrumetalita studia záporná, což znamená, že se studenti domnívají, že když se budou učit, pravděpodobnost dosažení cíle se sníží.

Zaměříme-li se na souvislost instrumentality studia a důležitosti cílů, naznačují výsledky s výjimkou cílů Vystudovat střední školu a Mít úspěšnou pracovní kariéru (velká důležitost i instrumentalista učení), že cílům, které studenti označují jako nejdůležitější, jsou zároveň přisuzovány poměrně malé hodnoty instrumentality učení. Jedná se především o cíle spojené se sociálními vztahy, rodinou a výchovou dětí.

\subsection{Atribuční tendence při plnění cílů}

Ve třetím kroku jsme se soustředili na zmapování atribučních tendencí u jednotlivých cílů. Pozitivním zjištěním je, že u převážné většiny cílů převažuje vnitřní atribuce, a to především vnitřní a kontrolovatelná (píle, úsilí). Dominantní úlohu zaujímá především u cílů, které úzce souvisí se školou: Vystudovat střední školu, Mít úspěšnou pracovní kariéru, Mít dobré známky, Stále se v něčem zlepšovat.

Dále nás zajímalo, zda se prokáže statisticky významný rozdíl v průměrech hodnot důležitosti, instrumentality a prospěchu u studentů, kteří atribuují vnějším nekontrolovatelným příčinám (náhoda, štěstí), resp. vnitřním kontrolovatelným prríčinám (píle, zaujetí). Výsledky prokazují u většiny prověřovaných cílů vysoce významný, resp. významný rozdíl $\mathrm{v}$ připisované důležitosti jednotlivým cílům u žáků z hlediska jejich atribučních tendencí. Všechny významné rozdíly jsou ve směru větší tendence $\mathrm{k}$ vnitřní, ovlivnitelné atribuci (píle) u studentů, kteří př̌ipisují větší důležitost určitému cíli. U proměnné instrumentalita nejsou výsledky již tak jednoznačné. U většiny cílů nebyl prokázán rozdíl v atribuční tendenci u studentů, kteří připisují cílům větší instrumentalitu. U studentů prospěchově slabších a prospěchově lepších se ukázaly ještě menší rozdíly.

\section{Další výzkumné kroky}

Budeme zjišt'ovat, zda existuje vazba mezi připisovanou důležitostí a připisovanou instrumentalitou. Zda ti, co připisují určitým cílům větší důležitost, mají zároveň tendenci připisovat i větší instrumentalitu učení pro dosažení těchto cílů. Obdobně budeme hledat propojení sledovaných cílů s prospěchem, resp. vnímanou důležitostí cílů a prospěchem. Pro upřesnění vazeb mezi proměnnými a především jejich vazeb na prospěch chceme využít faktorové analýzy a regresní analýzy (ANOVA), která nám umožní zjistit, jak závisí kritérium prospěchu na důležitosti, atribuční příčině, instrumentalitě a volních vlastnostech žáků. U cílů, kde budou výsledky faktorové analýzy a regresní analýzy v souladu, můžeme předpokládat větší průkaznost. Pomocí kvalitativní analýzy bychom se rádi podrobněji věnovali těm cílům, které souvisí se školním výkonem (prospěchem). Motivační sílu předpokládáme $v$ těch prrípadech, kde je připisována důležitost cíli, instrumentalita učení pro tyto cíle a vnitřní atribuce. 


\section{Závěr}

Studenti se především shodují na důležitosti vystudovat střední školu, za důležité považují i mít úspěšnou pracovní kariéru. Na předních místech důležitosti jsou dále umístěny především cíle ze sociální a vztahové oblasti. Zároveň však pro splnění těchto cílů proživají malou instrumentalitu učení. U cílů, které souvisejí se školou a pracovní kariérou, vnímaná instrumentalita učení stoupá. Pozitivním zjištěním je, že u většiny cílu dominuje vnitřní atribuce. Výzkum potvrzuje oprávněnost odlišovat důležitost cílů od proměnné instrumentalita učení. V další práci bychom se rádi věnovali otázkám, jak sledované motivační faktory samostatně a především ve vzájemných kombinacích ovlivňují vnímanou psychologickou distanci (a tím i účinnost) budoucích cílů (událostí). Vedle hodnoty cíle, vnímané instrumentality učení, atribučních tendencí a volních vlastností chceme zkoumat i jedincovu orientaci na budoucnost a objektivní časovou distanci cíle (události). Prezentovaná pilotní studie přinesla řadu podnětů, které budou využity pro tvorbu hypotéz pro další výzkumnou práci v rámci rozsáhlejšího výzkumu motivačních zdrojů učební činnosti, výzkumu motivačních aspektů vztahu studentů $\mathrm{k}$ budoucnosti a problematiky autodiagnostiky učitele (Hrabal \& Pavelková 2010).

\section{Literatura}

De Volder, M., \& Lens, W. (1982). Academic achievement and future time pespective as a cognitive motivational concept. Journal of Personality and Social Psychology, 42(1), 566-571.

Heckhausen, H. (1977). Achievement motivation and its constructs: A cognitive model. Motivation and Emotion, 1(4), 283-329.

Hrabal, V., Man, F., \& Pavelková, I. (1989). Psychologické otázky motivace. Praha: SPN. Hrabal, V., \& Pavelková, I. (2010). Jaký jsem učitel. Praha: Portál.

Irwin, F. W. (1971). Intentionel behavior and motivation. A cognitive theory. Philadelphia: Lippincott.

Pavelková, I. (2002). Motivace žákio k učení. Praha: PedF UK v Praze.

Pavelková, I., Purková, V., \& Menšíková, V. (2010). Časová perspektiva jako významný regulativ $\mathrm{v}$ lidském životě. Fenomén času ve výchově a vzdélávání, 15(1), 29-45.

Saitlová, B. (2009). Žákovské připisování př́čin po úspěchu a neúspěchu (Diplomová práce). Praha: PdF UK v Praze.

Weiner, B. (1980). Human motivation. Los Angeles: Holt, Rinehart and Winston.

Weiner, B. (2005). Motivation from an attribution perspective and the social psychology of perceived competence. In A. J. Elliot \& C. S. Dweck (Eds.), Handbook of competence and motivation. New York: Guilford.

\section{Kontakt}

Doc. PhDr. Isabella Pavelková, CSc.

Mgr. Barbora Saitlová

Univerzita Karlova v Praze

Pedagogická fakulta, Katedra psychologie

M. D. Rettigové 4,116 39 Praha 1

e-mail: jfpavelka@volny.cz

barborasaitlova@seznam.cz

\section{Bibliografické údaje}

Pavelková, I., \& Saitlová, B. (2011). Instrumentalita učení z hlediska budoucích cílů. In T. Janík, P.

Knecht, \& S. Šebestová (Eds.), Smíšený design v pedagogickém výzkumu: Sborník př́spěvkũ z 19.

výroční konference České asociace pedagogického výzkumu (s. 429-433). Brno: Masarykova univerzita.

Dostupné z: http://www.ped.muni.cz/capv2011/sbornikprispevku/pavelkovasaitlova.pdf

doi: $10.5817 /$ PdF.P210-CAPV-2012-43 